In "The Interrelations of the Biometric and Experimental Methods of acquiring Knowledge: with especial Reference to the Problem of the Duration of Life," Prof. Pearl has published the substance of a lecture delivered to the Harvey Society in April 1922. As an illustration of the usefulness of the statistical method, he refers to his study of the duration of life in the fruit-fly, Drosophila melanogaster, in the American Naturalist, vol. 55, I92I. He constructed life-tables for 5400 male and 6332 female flies of this species, grown under constant conditions of temperature, food supply, etc. He finds an analogy between the life-span of the imaginal stage of the fly with a limit of 97 days, to which only one out of Iooo flies survives, and a human life-span of 86 years, the difference between 98 years, where $I$ in 1000 survives in the American life-table, and 12 years, at which age the death-rate is at a minimum. These two life-spans he considers comparable, I year of human life being equal to I'I279 days of Drosophila life.

Prof. Pearl finds that the form of the $l x$ distributions, or degrees of longevity, is fundamentally the same in the two over the equivalent life-spans, from which he concludes that " the factors that determine individual longevity, and differences in this character, are biologically deeply rooted, and are at least as fundamental, apparently, as the factors which determine the specificity in the morphogenesis of organisms." While the laws of mortality are fundamentally the same in kind, they differ, however, quantitatively, as the human being has at every age a higher expectation of life than Drosophila. He puts forward the suggestion, although he states that it requires further research for verification, that this may be due to improvement of environment by hygiene. As the flies are kept under more or less ideal conditions, however, it is difficult to accept such an explanation. Pearl has shown, moreover, that different stocks of Drosophila show wide differences in duration of life. There are long-lived and short-lived strains. By suitable crossing experiments with the different strains he has also shown that segregation of these takes place in a Mendelian manner and that the differences are found to be constant.

"The Influence upon Duration of Life of certain mutant Genes of Drosophila melanogaster," published recently in the American Naturalist (vol. 57, JulyAugust I923) by B. M. Gonzalez, is based on another of the experimental studies on the duration of life conducted in the Department of Biometry and Vital Statistics, Johns Hopkins University. The paper is a first attempt at localising, in the chromosomes, factors controlling the duration of life.

Two stocks were used, namely-(I) a wild type of fly, (2) a " quintuple" stock, the latter a synthetic stock carrying five second chromosome mutations each in homozygous form, as follows: (a) black, a body colour factor; (b) purple, an eye colour; (c) vestigial, a rudimentary wing condition; (d) arc, a mutation with arched wings; $(e)$ speck, a black spot on the wing.

These five mutants in the second chromosome of Drosophila were used as indices for five distinct factors that were recognised as having a definite effect on the duration of life. By crossing the quintuple stock with the wild stock twenty-two different combinations were obtained. These, with the two original, gave twenty-four strains in all. The behaviour of these combinations with respect to duration of life was investigated in 24,287 flies. The results obtained appear to show that under constant environmental conditions definite degrees of duration of life are associated with " extreme precision and exactness " with the presence or absence of certain genes of the chromosome. These same genes also appear to control certain morphological characters.

\section{The New Science Department of Mill Hill School.}

A SCIENCE building to-day must do more than provide accommodation for the science teaching of a school. It must express both in its structure and in its utilitarian possibilities those ideas which underlie the new conception of education which has been arising since the War. It must show a future generation what we are now feeling after, and must give them what we think they will want.

Such ideas are spaciousness, liberty, and a sense of adventure in life; self-determination, and education in the right use of leisure. The use of leisure was the theme of discussion at the conference of schoolmasters and university teachers at Cambridge in January I923, and the science buildings at Mill Hill School, which were opened by H.R.H. the Prince of Wales on February 2r, are to some extent the outcome of what was learnt there. The achievement of one of the boys, who, under great difficulties and with home-made apparatus, has maintained steady twoway communication with American amateurs while the building has been in progress, gave special point to the Prince's reference to such ideas. "The work," he said," "is clone by a boy in his spare time : and I consider the proper and profitable use of spare time plays a very big part in education nowadays. To do things worth doing by ourselves, for ourselves, and because we want to do them-that only is the right way to use one's leisure. All that is necessary is opportunity, and these buildings, in addition to their formal use, create opportunity for Mill Hill boys." The Prince referred to the provision of opportunity for research side by side with formal teaching and for the pursuit of mechanical and scientific hobbies.

The new science schools were designed by $\mathrm{Mr}$. Stanley Hamp to take advantage of a sloping site, providing a basement 24 feet wide; this runs the whole length of the building, and forms an ideal workshop. Here, too, is a motor room and an accumulator room giving direct current to the laboratories above. The central room on the ground floor is an octagonal museum lined with cupboards and forming the storage for physical apparatus. From this central hall access is gained to the two physical laboratories, each with its own optical room, and to the physics lecture room and the geography department. A short stairway descends to the basement, a portion of which is the physical workshop. A useful preparation room and a photographic dark room fill up odd corners. On the first floor are two large chemical laboratories, a biology room, and a chemistry lecture room, all communicating with a central store room. Here the well which lights the museum below is surrounded by a working bench, and the room forms a convenient research laboratory without interfering with its other uses. There is also a wireless room, a photographic enlarging room, a reference library, and a masters' room. The roof is interesting and valuable. The gabled portion surrounds a well concealing the chimney-an excellent arrangement for aerial and counterpoise. Around it is a walk commanding fine views. In front is an asphalt flat of obvious value.

The Prince of Wales praised the beauty of the buildings, which are designed as much to be a place in and from which a boy can receive impressions, as a place in which he can learn science or pursue a handicraft. The structural beauty of the building, which is part of Mill Hill School War Memorial, and its use, should alike make their appeal to his sense of the spaciousness and adventure of life.

W. H. Brown.

NO. 2835 , vOL. I I 3$]$ 